\title{
POTENSI DESA ALOR KECIL SEBAGAI DESA WISATA DI KABUPATEN ALOR NUSA TENGGARA TIMUR
}

\author{
Elim Roberth Anderson Lau,SE.,M.Par \\ Jurusan Pariwisata, Politeknik Negeri Kupang \\ Jl. Adisucipto Kampus Penfui-Kupang NTT \\ E-mail: elimralau@mail.com
}

\begin{abstract}
Abstrak
Alor kecil merupakan salah satu desa dipinggir pantai yang memilik pantai yang indah di Kabupaten Alor. Selain memiliki budaya yang kuat,Desa Alor Kecil memiliki potensi taman laut yang sangat bagus. Salah seorang penyelam asal Jerman mengatakan "Pantai Alor Kecil memiliki lebih dari 26titik selam yang sangat indah" dengan melihat potensi tersebut, patutlah Desa Alor Kecil dikembangkandan dikelola dengan baik agar wisatawan yang berkunjung bisa memberikan dampak positif bagi wargamasyarakat disekitar lokasi wisata. Namun disisi lain, kurangnya perhatian khsusus dari Pemerintah Kabupaten Alor serta minimnya sumber daya manusia yang ahli dibidang pariwisata membuat pantai diDesa alor Kecil tidak dikelola secara optimal.Tujuan dari Penelitian ini adalah untuk melihat potensi yang ada di Desa Alor Kecil serta kendala- kendala yang diihadapi.

Strategi pemasaran yang dilakukan meliputi: penentuan strategi lokasi, harga Strategi dengan metode cost plus pricing, dan strategi pertumbuhan produk jasa produk yangberkualitas baik atau berbeda dari desa-desa wisata lain, promosi melalui website, strategi ofensifmerupakan strategi yang difokuskan pada upaya perubahan untuk mencapai tingkat yang lebih baik danpelatihan sumber daya manusiaUntuk mengatasi hambatan atau kendala tersebut dirumuskan strategi untukmemberdayakan dan mengembangkan potensi pariwisata yang terdapat di kawasanpedesaan antara lain meningkatkan dan mengembangkan jenis produk pariwisata pedesaan, memperbaiki dan meningkatkan aksesibilitas menuju obyek dan daya tarik wisata pedesaan, meningkatkan promosi dan pemasaran produk pariwisata pedesaan, meningkatkan kerja sama dengan berbagai pihak terkait, mendirikan Tourist Information Center (TIC) di daerah pedesaan, membentuk dan membina kelompok sadar wisata, memberikan penyuluhan, pengarahan dan penjelasan tentang pentingnya pariwisata bagi pengembangan perekonomian daerah dan peningkatankesejahteraan masyarakat..
\end{abstract}

Kata kunci : potensi desa wisata, kendala, strategi pengembangan.

\section{PENDAHULUAN}

Pada hakekatnya pembangunan merupakan suatu upaya secara terus menerusuntuk mencapai tingkat kesejahteraan masyarakat. Upaya ini meliputi pengembangan wilayah dan pemerataan pembangunan dalam rangka pelayananpublik yang meliputi pemenuhan kebutuhan dasar ekonomi dan sosial serta pemberian kesempatan kepada masyarakat untuk berpartisipasi dalam pembangunan daerah.

Demikian halnya dengan sektor pariwisata, pembangunansektor ini memiliki sejumlah peran strategis untuk mendorong pembangunan ekonomi daerah maupun nasional, pengembangan wilayah dan daerah tertinggalmelalui aktifitas kepariwisataan, mendorong upaya pelestarian dan pengembangansumber daya alam dan budaya, serta mendorongpeningkatan kesejahteraan ekonomi masyarakat atau disebut juga pemberdayaan masyarakat.
Pariwisata merupakan bagian yang tidak terpisahkan dari kehidupan manusia terutama menyangkut kegiatan sosial dan ekonomi.Diawali dari kegiatan yang semula hanya dinikmati oleh segelintir orang-orang yang relatif kaya pada awal abad ke-20, kini telah menjadi bagian dari hak asasi manusia, sebagaimana dinyatakan oleh Naisbitt (1994), bahwa once2 travel was considered a privilege of the moneyed elite, now it is considered abasic human right. Hal ini terjadi tidak hanya di negara maju tetapi telah dirasakan pula di negara berkembang termasuk pula Indonesia.Dalam hubungan ini, berbagai negara termasuk Indonesia pun turut menikmati dampak dari peningkatan pariwisata dunia terutama pada periode tahun 2014 sampai dengan 2015.

NTT adalah wilayah kepulauan terdiri dari 566 pulau (432 pulau sudahmempunyai nama, 134 belum mempunyai nama). Sebanyak 42 pulau berpenghuni, sisanya belum berpenghuni. didiami oleh 22 etnis dengan 
keanekaragaman ciri fisik, bahasa, latar belakang sejarah, adat istiadat, agama danlingkungan fisik. Luas wilayah daratan $47.349,90 \mathrm{~km} 2$ atau 2,49\% luas Indonesia4 dan luas wilayah perairan $\pm 200.000 \mathrm{~km} 2$ diluar perairan Zona Ekonomi Eksklusif Indonesia (ZEEI).Hal ini sesuai dengan yang dikemukakan Kurniawan (2005) dalam studinyamenyebutkan bahwa konsep pengembangan desa wisata dapat dilihat daridefinisinya, yaitu merupakan suatu bentuk pariwisata dengan objek dan daya tarik wisata berupa kehidupan desa yang memiliki ciri khusus dalam masyarakatnya, panorama alam, hasil budayanya, sehingga mempunyai peluang untuk dijadikan komoditi bagi wisatawan.

Pendekatan perencanaan pengembangan desa wisata yang bisa dilakukan adalah community approach atau community based development. Dalam hal inimasyarakat lokal yang akan membangun memiliki dan mengelola langsungfasilitas wisata serta pelayanannya sehingga dengan demikian masyarakat diharapkan dapat menerima secara langsung keuntungan ekonomi serta mencegah urbanisasi (Marpaung, 2000) Sejauh ini, kondisi potensi pariwisata yang ada di desa Alor Kecil belum dikelola secara optimal, hal ini lebih disebabkan oleh kondisi masyarakat yang belum sepenuhnya mengerti akan arti penting pariwisata terutama desa wisata. Disamping itu pula belum adanya arahan pengembangan serta strategi pengembangan kegiatan pariwisata yang berbasis kepada kearifan lokal masyarakat desa wisata. Kenyataan ini dapat terlihat di desa Alor Kecil dimana potensi-potensi pariwisata seperti taman laut selat Pantar yang ada dibiarkan begitu saja dan masyarakat di Desa Alor Kecil hanya sebagai penonton dan bukan pelaku pariwisata.

\section{RumusanMasalah}

1. Bagaimanakah Potensi Desa Alor Kecil sebagai sebuah Desa Wisata dilihat dari segi kekuatan, kelemahan, peluang dan ancaman?

2. Faktor-faktor apakah yang memengaruhi pengembangan Desa wisata diDesa Alor Kecil?

3. Apa saja kendala-kendala yang akan dihadapi dalam pengembangan DesaWisata di desa Alor Kecil?

TujuanPenelitian

1. Untuk Mengetahui potensi Desa Alor Kecil sebagai Desa Wisata
2. Faktor-faktor apakah yang memengaruhi pengembangan Desa Wisata diDesa Alor Kecil.

3. Untuk mengetahui kendala-kendala yang akan dihadapi dalampengembangan Desa Wisata di Desa Alor Kecil.

\section{Manfaat dan Signifikansi Penelitian}

1. Terdatanya potensi esa Alor Kecil sebagai daerah tujuan wisata perdesaan

2. Teridentifikasinya kendala-kendala dalam pengembangan Desa Wisata

3. Teridentifikasinya faktor-faktor yang memengaruhi pengembangan

DesaWisata di Desa Alor Kecil.

\section{KERANGKA TEORITIS}

\section{Tinjauan Pustaka}

Pariwisata terdiri dari kegiatan orang bepergian ke dan tinggal di tempattempatdi luar mereka Lingkungan yang biasa tidak lebih dari satu tahun berturut turut untuk bersantai, bisnis dan lainnya tujuan tidak terkait dengan pelaksanaan suatu kegiatan dibayar dari dalam tempat dikunjungi (World Tourism

$$
\text { Organization/WTO) Przeclawski }
$$

menyatakan bahwa pariwisata bukan hanya masalah ekonomi, tetapi juga psikologi, sosial dan budaya. Pariwisata juga memikirkan masalah rasa dan pengalaman dari suatu 'setting' sosial, memahami diri sendiri di lingkungan yang baru, misalnya di lingkungan yang 'indah'. MacIntosh and Goeldner (1986) menyatakan bahwa pariwisata bisa didefinisikan sebagai semua fenomena dan keterkaitan yang muncul karena interaksi wisatawan, bisnis penyedia jasa, pemerintah dan komunitas setempat, dalam proses mendatangkan wisatawan atau pengunjung. Spillane (1994) : Pariwisata adalah perjalanan dari suatu tempat ke tempat lain bersifat sementara, dilakukan perorangan ataupun kelompok sebagai usaha mencari keseimbangan, keserasian dalam dimensi sosial budaya alam dan ilmu.

Sebagai satu proses dalam penyusunan perencanaan kawasan desa wisata dibutuhkan suatu tindakan pemeliharaan yang terbaik/menguntungkan dari berbagai alternatif dalam usaha pencapaian tujuan. Mengingat perencanaan kawasan desa wisata lebih banyak melibatkan peran, partisipasi dan pemberdayaan masyarakat, maka bentuk perencanaannya lebih menitik beratkan kepada Community Based Tourism.Seperti yang telah dikatakan di atas, CBT muncul sebagai alternatif

Pariwisata utama. Sementara CBT adalah sebagian besar tergantung pada infrastruktur 
pariwisata yang sama seperti pariwisata utama, terutama untuk transportasi, CBT dipandang sebagai alternatif dan sangat sedikit inisiatif CBT terhubung dengan industri pariwisata utama, akses pasar proyek CBT karena itu umumnya miskin. Terkait dengan penolakan ini pasar adalah komitmen untuk manfaat masyarakat kolektif dan tata kelola masyarakat. Meskipun penelitian oleh Rainforest Alliance menunjukkan bahwa $40 \%$ dari Proyek CBT di negara berkembang tidak melibatkan masyarakat dalam pengambilan keputusan, $60 \%$ melakukan melibatkan beberapa bentuk keterlibatan masyarakat dalam pengambilan keputusan. Mitchell dan Muckosy (2008) mengaitkan ini dengan tata kelola yang buruk yang mereka melaporkan sebagai ciri khas CBT. Ada kekakuan cukup dalam penggunaan konsep Community Based Tourism. Konsep digunakan secara fleksibel.

\section{Kerangka Berpikir}

Guna memudahkan penelitian mengenai pengembangan Pariwista Pedesaan (Suatu Usulan tentang Potensi Desa Alor Kecil Sebagai Salah Satu Desa Wisata di Kabupaten Alor).

\section{METODELOGI}

Penelitian terfokus pada identifikasi potensi wisata yang ada di Desa Alor Kecil, Kabupaten Alor. Metode penelitian yang digunakan adalah metode deskriptif kualitatif. Dimana metode deskriptif menurut Antara (2010), adalahpenelitian yang berusaha mendeskripsikan atau menggambarkan atau melukiskan fenomena atau hubungan antar fenomena yang diteliti dengan sistematis, faktual dan akurat. Metode penelitian deskriptif ini tidak selalu membutuhkan hipotesis, demikian pula dengan perlakuan atau manipulasi terhadap variabel-variabel penelitian. Penelitian deskriptif bertujuan untuk mendeskripsikan gejala-gejala yang terjadi dilakukan secara sistematis dengar terhadap variabel-variabel penelitian.

Penelitian deskriptif bertujuan untuk mendeskripsikan gejala-gejala yang terjadi dilakukan secara sistematis dengan menekankan pada data faktual.

Sedangkan kualitatif adalah jenis penelitian yang temuan-temuannya tidak diperoleh melalui prosedur statistik atau bentuk hitungan lainnya. (Antara ; 2010)Sedangkan menurut Variabel penelitian menurut Umar (2000) sesuatu hal yang berbentuk apa saja yang ditetapkan oleh peneliti untuk dipelajari sehingga diperoleh informasi tentang hal tersebut, kemudian ditarik kesimpulannya.
Selain itu variabel adalah konsep yang mempunyai bermacam-macam nilai (Sudjana, 1996) strategi pengembangan daerah tujuan wisata.

Variabel tersebut terdiri dari 5 (lima) sub variabel yang nantinya akan diteliti dengan pengukuran secara kualitatif. Pengukuran dilakukan dengan berbagi jenis data atau informasi yang dikumpulkan. Data kualitatif terdiri dari deskripsi yang terperinci pada suatu keadaan, peristiwa, orang, interaksi, dan pengamatan tingkah laku; pernyataan langsung dari orang mengenai pengalaman mereka, sikap, keyakinan, dan ide-ide; dan beberapa kutipan atau seluruh bagian dari dokumen, surat menyurat, rekaman, dan kasus-kasus sejarah. Deskripsi secara terperinci, pernyataan langsung, dan dokumentasi peristiwa adalah bagian empiris dari data kasar sebuah pengukuran kualitatif. Data dikumpulkan sebagai naratif yang tidak terbatas tanpa uji coba untuk menyesuaikan program kegiatan atau pengalaman seseorang hingga sebelumnya menentukan kategori standar seperti pilihan jawaban yang terdiri dari tipe pertanyaan atau tes.

Teknik Pengumpulan Data Metode penelitian lapangan (Field Research) yaitu metode pengambilan data yang dilakukan melalui pengamatan secara langsung di lokasi penelitian sebagai berikut : Pengamatan/Observasi,wawancara serta dokumentasi.Metode analisis data analisa data merupakan bagian yang amat penting dalam metode ilmiah karena dengan analisis data tersebut dapat diberi arti dan makna yang berguna dalam memecahkan masalah penelitian. Untuk menjawab tujuan dan permasalahan penelitian, maka setelah data dikumpulkan dan diolah atau diproses, selanjutnya dianalisis dengan menggunakan metode analisis SWOT.

\section{Waktu dan Lokasi Penelitian}

Penelitian ini dilaksanakan pada bulan April tahun 2015 yang bertempat diDesa Alor Kecil Kabupaten Alor.

\section{HASIL DAN PEMBAHASAN}

\section{Gambaran Umum Lokasi Penelitian}

Desa Alor Kecil merupakan sebuah desa yang berada di pesisir pantai sebelah barat Kabupaten Alor. DesaAlor Kecil yang pada dasarnya terbentuk dari Pemerintahan Adat yang kemudian berdasarkan keputusan Menteri Dalam Negeri N0 03 Tahun 1981 dikukuhkan menjadi Desa Alor Kecil dengan luas wilayah $132 \mathrm{Ha}$. JumlahPenduduk 1685 Jiwa yang terdiridari Laki-laki 841 jiwa dan 
perempuan 844 jiwa dan jumlah kepala keluara sebanyak $443 \mathrm{KK}$.

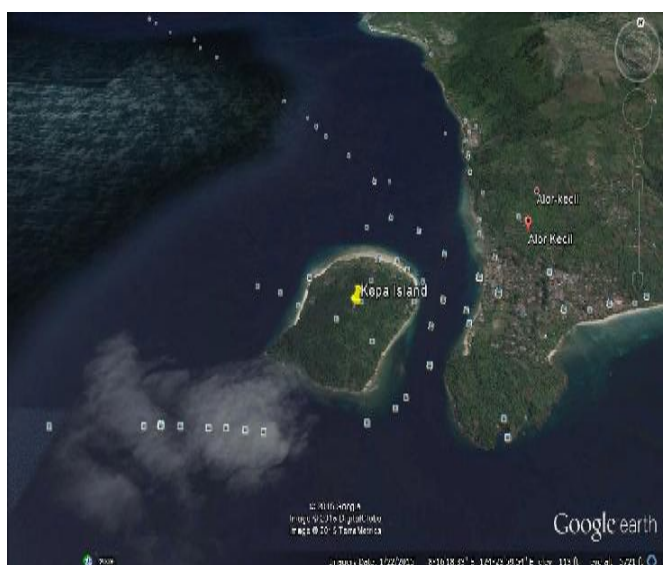

Gambar.1. Lokasi Wilayah Desa Alor Kecil Sumber : Google Earth

Melihat dari segi topografi Desa Alor Kecil yang terletak di kawasan pesisirpantai, dan juga dataran dan perbukitan dengan kondisi tanah yang tandus. Sehingga mata pencaharian Masyarakat Desa Alor kecil sangat beragam namun pada Umumnya adalah Nelayan dan Petani namun ada juga yang berprofesi sebagai Pedagang/Papalele, Ternak, Industri kecil serta PNS dan lain-lain.

Batas sebelah Timur dengan Desa Lefokisu,Batas sebelah Barat dengan Pulau Pura, Batas sebelah Utara dengan Desa Alor besar, Batas sebelah Selatan denganTeluk Kabola.

Melihat dari segi topografi Desa Alor Kecil yang terletak di kawasan pesisir pantai, dan juga dataran dan perbukitan dengan kondisi tanah yang tandus. Sehinggamata pencaharian Masyarakat Desa Alor kecil sangat beragam namun padaUmumnya adalah Nelayan dan Petani namun ada juga yang berprofesi sebagaiPedagang/Papalele, Ternak, Industri kecil serta PNS dan lain-lain

\section{Potensi Desa Alor Kecil}

Di desa Alor Kecil, terdapat pulau Kepa yang juga memiliki pantai bagus danair laut yang bersih. Masyarakat di Pulau Kepa bekerja sebagai Nelayan dan jugamasyarakat disana sudah mempunyai 5 rumah yang dijadikan sebagai Rumah Inapatau Homestay. Masyarakat di Pulau Kepa sering menangkap ikan dengan menggunakan Bubu, dan masyarakat juga sering mengajak para wisatawan untukbersama-sama menangkap ikan dengan menggunakan Bubu.

\section{Faktor-faktor yang Memengaruhi Pengembangan Desa Wisata Alor Kecil}

Dalam pengembangan suatu Desa Wisata, akan selalu ada faktor-faktor yangbisa memengaruhi suatu kawasan menjadi Desa Wisata Abdullah Mamala selaku Kaur Pembangunan Desa Alor Kecil dan juga Aktifis kelompok sadar wisata mengatakan:

"Selain alam bawah laut yang menawan, masyarakat khususnya pemuda disinisudah mulai sadar akan pentingnya pariiwisata di Desa Alor Kecil. Oleh karenaitu, kami mengadakan pertemuan rutin seminggu sekali untuk membahas tentangcara memandu wisatawan baik itu lokal maupun mancanegara. Walapun denganketerbatasan akan pengetahuan tentang pariwisata, namun setidaknya kamilebih menekankan pada keramahtamahan dalam menyambut dan melayani tamuatau wisatawan."

Dengan tersedianya faktor-faktor yang mendukung akan suatu desa wisata, patutlah dikembangkan dan dikelola secara optimal agar terjadinya keberlanjutan pariwisata. Serta masyarakat merasakan dampak yang timbul dari desa wisata tersebut. Antara lain, menciptakan lapangan pekerjaan, pembangunan di desa serta pariwisata juga sebagai sumber devisa. (Spillane 1994: 5162).

Kendala yang akan dihadapi dalam pengembangan Desa Wisata di Desa Alor Kecil.

Terlepas dari potensi dan ketersediaanya faktor-faktor pendukung suatu kawasan wisata, ada pula kendala-kendala yang akan dihadapai dalam suatu desa wisata. Dan yang ditemui dalam Desa Alor Kecil adalah kurangnya sumber daya manusia dalam megelola desa wisata. Sari Bandoso, Ketua Jurusan Pariwisata Politeknik Negeri Kupang selaku akademisi yang berkecimpung dalam dunia pariwisata mengatakan:

"Kalau kita berbicara mengenai sumber daya manusia, memang kami sangatterbatas sumber daya manusia dibidang pariwisata sehingga pengelolaan potensiwisata kurang optimal dan cenderung tidak berjalan sesuai harapan."'Kami melihat potensi wisata di Nusa Tenggara Timur sangat banyak, oleh karenaitu kami membuka jurusan Pariwisata agar bisa mendapatkan pemuda yang pahamdan pintar dibidang pariwisata. Harapan kami, 5 tahun mendatang, sumber dayamanusia dibidang pariwisata sudah terpenuhi".

Dengan kendala yang dihadapi masyarakat adalah kurangnya penyuluhan dan sosialisasi tentang pariwisata agar mereka bisa 
memahami apa yang harus diilakukan. Tenaga ahli dalam bidang pariwisata akan sangat membatu dalam mengelola kawasan wisata menjadi suatu daya tarik. Serta kurangnya biro perjalanan wisata yang memasarkan kawasan wisata yang ada di Kabupaten Alor.

\section{Strategi Pengembangan Berdasarkan Analisis SWOT}

Berdasarkan temuan di lapangan maka strategi pemasaran yang dapat direalisasikan analisis lingkungan internal / Internal Factors Analysis Summaryl IFAS (Kekuatan dan Kelemahan) Desa Wisata Alor Kecil yaitu : Kekuatan (strengths) a) Lokasi yang strategis tepat berada dijalan utama penghubung kecamatan dan searah dengan kawasan wisata Pantai Sebanjarb) Kualitas pelayanan yang baik dan ramah.c) Memiliki pantai yang bersih dan alam bawah laut yang bagus.d) Dukungan dari Masyarakat sekitar serta sudah adanya kelompok sadarwisata yang digalang oleh Kepala Desa.e) Sudah tersedianya pemandu lokal.f) Tersedianya fasilitas pendukung berupa Puskesmas rawat inap danBank. Kelemahan (weaknesses)a) Wisata Alor Kecil merupakan sebuah Desa Wisata yang baru berdiri sehingga belum dikenal oleh konsumen $b$ ) Pegawai pemerintahan yang belum profesional dan ahli didalam menangani desa wisata $\mathrm{c}$ ) Petugas dari Desa Wisata Alor Kecil tidak memiliki pengalaman dan latar belakang pendidikan dibidang desa wisata karena karyawan yang direkrut adalah anak SMA yang telah tamat dan tidak melanjutkan pendidikannya kejenjang selanjutnya yang memiliki kemampuan berkomunikasi yang baik terutama bahasa inggris dan memiliki keinginan untuk belajar.

Analisis Lingkungan Eksternal / External Factors Analysis Summary /EFAS (Peluang dan Tantangan) Desa Wisata Alor Kecil Peluang (opportunities)a) Desa wisata yang memiliki pangsa pasar masih terbatas sehingga terdapat peluang untuk mengambil pasar $b$ ) Jumlah kunjungan wisatawan I o $\mathrm{k}$ a I yang melakukan kegiatan semakin meningkat. Tantangan (threats)a) Persaingan dengan Desa Wisata yang memiliki pangsa pasar yang sama b) Situasi dan kondisi keamanan dan kestabilan politik di Indonesia seperti ancaman teroris, atau bentrokan antar suku yang sering terjadi di Kabupaten Alor c) Keadaan alam dan budaya di Alor yang tidak dijaga dengan oleh masyarakat Alor dapat menyebabkan wisatawan tidak akan datang berkunjung ke Alor terutama untuk masalah sampah.

Strategi yang diperoleh berdasarkan analisis SWOT dapat diuraikan sebagai berikut: Strategi S-O

Strategi penetapan lokasi atau outlet dilakukan untuk mengenalkan produkDesa Wisata Alor Kecil kepada calon wisatawan. Desa Wisata Alor Kecil memiliki lokasi yang strategis yang berada dijalur utama jalan penghubung desa di Kabupaten Alor sehingga mudah untuk mencapai Desa Wisata ini, memiliki parkir yang cukup dan aman dari macam-macam gangguan serta lokasi yang menarik sehingga nyaman untuk melakukan kegiatan transaksi penjualan dari unit bisnis yang dimiliki oleh Desa Wisata ini, Strategi harga yang digunakan oleh Desa Wisata Alor Kecil adalah metode cost plus pricing dengan menetapkan margin yang diinginkan oleh Desa Wisata dengan harga yang lebih rendah dibandingkan dengan pesaing, Product growth strategies di mana Desa Wisata Alor Kecil memiliki beberapa produk jasa yang berkualitas lebih baik atau berbeda dengan produk lain, dengan tujuan agar memiliki kesempatan untuk meningkatkan pangsa pasar dengan menarik pelanggan yang berbeda, Kelengkapan pembuatan selebaran kemudian disebarkan di lokasi-lokasi stragtegis misalnya Bandar Udara dan Pelabuhan laut serta majalah untuk penerbangan lokal maupun nasional hingga inernasional.

\section{Strategi W - O}

Promosi Desa Wisata Alor dilakukan melalui website yang memberikaninformasi tentang produk-produk yang dimiliki dan gambaran umum mengenaiKabupaten Alor selain itu untuk melakukan promosi yang benar dan tepat sasaran dan sekaligus melalui word of mouth untuk wisatawan lokal dan domestik dengan alamat website.

\section{Strategi S -T}

Melakukan offensive strategy merupakan strategi yang lebih menitikberatkanpada usaha perubahan untuk mencapai tingkat yang lebih baik. Bentuk strategiini dapat berupa modifikasi pasar, yaitu dengan menggaet kelompok bukanpemakai (non-user) mengintensifkan penawaran Desa Wisata Alor Kecil kepada non-user, dan merebut konsumen pesaing. Bentuk lain dari strategi ini adalah modifikasi produk, yaitu mengubah karakteristik produk sedemikian rupa, sehingga semakin menarik konsumen saat ini untuk membeli dengan cara menawarkan manfaat baru dari suatu produk kepada konsumen sekarang untuk mendorong kunjungan yang lebih banyak dan lebih sering dengan melakukan diversifikasi produk terhadap beberapa aktivitas tur dan paket lainnya yang dapat digabung dengan produk 
tersebut.

\section{Strategi $\mathbf{W}-\mathbf{T}$}

Melakukan training karyawan dibidangnya masing-masing di mana DesaWisata Alor Kecil selalu melakukan pelatihan terhadap karyawan untuk memberikan standar pelayanan yang berkualitas dengan cepat dengan harga yang murah, Merancang proses kerja yang efisien dan efektif yang mengacu pada SOP (standard operating procedures).

\section{PENUTUP}

\section{KESIMPULAN}

Beberapa hal yang dapat disimpulkan dari penelitian adalah: Potensi yang terdapat di Desa Alor Kecil di Kabupaten Alor yang dapat dikembangkan sebagaidaya tarik wisata sangat beraneka ragam. Potensi tersebut antara lain adalah SentraKerajinan Tenun Ikat dan wisata Bahari Taman Laut Berbagai potensi tersebut sudah diberdayakan dan dikembangkan sebagai daya tarik wisata oleh pihak-pihak terkait, khususnya Pemerintah Kabupaten Alor dan Pemerintah Propinsi Nusa Tenggara Timur. Upaya pemberdayaan tersebut antara lain dalam bentuk menyediakan dan mengembangkan berbagai amenitas (sarana penunjang) pariwisata, memperbaiki aksesibilitas menuju obyek dan daya tarik wisata pedesaan, meningkatkan kapasitas Sumber Daya Manusia (SDM), khususnya yang berkaitan langsung dengan pengembangan wisata pedesaan, meningkatkan promosi produk wisata pedesaan, serta mengembangkan kelembagaan yang dapat mendukung pembangunan wisata pedesaan.

Untuk mengatasi hambatan atau kendala tersebut dirumuskan strategi untukmemberdayakan dan mengembangkan potensi pariwisata yang terdapat di kawasan pedesaan antara lain meningkatkan dan mengembangkan jenis produk pariwisata pedesaan, memperbaiki dan meningkatkan aksesibilitas menuju obyek dan daya tarik wisata pedesaan, meningkatkan promosi dan pemasaran produk pariwisata pedesaan, meningkatkan kerja sama dengan berbagai pihak terkait, mendirikan Tourist/nformation Center (TIC) di daerah pedesaan, membentuk dan membina kelompok sadar wisata, memberikan penyuluhan, pengarahan dan penjelasan tentang pentingnya pariwisata bagi pengembangan perekonomian daerah dan peningkatan kesejahteraan masyarakat.

\section{IMPLIKASI KEBIJAKAN}

Dalam penelitian mengenai pemberdayaan potensi kawasan pedesaan
diKabupaten. Alor untuk mengembangkan perekonomian masyarakat desa terdapatbeberapa keterbatasan antara lain : Keterbatasa cakupan penelitian yang dalam hal ini hanya difokuskan pada Desa Alor Kecil Kecamatan Alor Barat Laut Kabupaten Alor, Keterbatasan key informants yang mengetahui secara baik hal-hal yang menjadi kendala serta hal-hal yang seharusnya dilakukan oleh berbagai pihak terkait dalam upaya mengembangkan potensi alam dan budaya yang terdapat di kawasan pedesaan untuk menunjang pemberdayaan perekonomian masyarakat desa melalui pembangunan pariwisata.

Berdasarkan hasil yang telah dicapai pada penelitian ini disusun rekomendasiyang perlu ditindaklanjuti pada tahun-tahun berikutnya. Rekomendasi tersebutadalah : Perlu diadakan penelitian yang masih berkaitan dengan upaya pemberdayaan potensi alam dan budaya yang terdapat di kawasan pedesaan untuk menunjang pembangunan perekonomian masyarakat desa melaluipembangunan pariwisata, Perlu dilakukan penelitian yang dapat merumuskan bentuk kerja sama yang sinergis antara berbagai elemen pariwisata dan pembangunan perekonomian masyarakat pedesaan sehingga dapat mendukung upaya peningkatan kesejahteraan masyarakat pedesaan melalui pembangunan pariwisata pedesaan.

\section{SARAN}

Beberapa saran yang dapat diajukan berdasarkan hasil penelitian ini adalah :Kekayaan potensi alam dan budaya di daerah pedesaan yang dimiliki masyarakatKabupaten Alor khususnya di Desa Alor Kecil perlu diberdayakan dan ditingkatkan perannya untuk menunjang pembangunan pariwisata di Kabupaten Alor, Untuk menunjang pengembangan obyek wisata, aksesibilitas menuju ke obyek dan daya tarik wisata yang terdapat di berbagai kawasan pedesaan Alor Kecil perlu ditingkatkan, Sarana wisata termasuk akomodasi, catering facilities, sarana komunikasi, sarana transportasi, dan sarana terkait lainnya perlu ditingkatkan untuk memberi kemudahan baik kepada wisatawan maupun masyarakat setempat, Kegiatan wisata yang dapat dilakukan wisatawan pada saat mengunjungi obyek dan daya tarik wisata di Desa Alor Kecil perlu dikembangkan sehingga dapat memperpanjang lama tinggal wisatawan serta dapat memberikan pengalaman perjalanan yang khas kepada wisatawan, Meningkatkan partisipasi stakeholder pariwisata Kabupaten Alor untuk mengembangkan pariwisata daerah melalui 
pengembangan berbagai potensi alam dan budaya yang terdapat di kawasan pedesaan yang ada di Desa Alor Kecil.

\section{DAFTAR PUSTAKA}

Antara,M. 2010. Metodologi Penelitian Pariwisata. Denpasar

Mitchell J \& Muckosy P . 2008 A misguided quest: Community-based tourism in LatinAmerica ODI Opinion 102

Marpaung, Happy.2000. Pengetahuan Kepariwisataan.Bandung:Alfabeta.

Naisbitt (1994),. Concept, Perspective and Challenges, makalahbagiandariLaporanKonferensi InternasionalmengenaiPariwisataBuda ya.Yogyakarta: GadjahMada University Press)

Przeclawski K. 1993. Tourism as the Subject of Interdisciplinary Research, in Tourism Research edited by D.G. Pearce, R. Butler, Routledge, chapter 2, pp.

Spillane J James, 1994. Ekonomi Pariwisata Sejarah dan Prospeknya. Penerbit Kanisius.

Umar, H. 2000. Metode Penelitian untuk Skripsi dan Tesis Bisnis, Cet. Ketiga. Penerbit 